Volume 3 Issue 1, March 2018: pp. 1-10. Copyright @ LamLaj. Faculty of Law, Lambung Mangkurat University, Banjarmasin, South Kalimantan, Indonesia. ISSN: 2502-3136 | e-ISSN: 2502-3128. Open Access at: http: //lamlaj.ulm.ac.id/web/

\title{
THE EXISTENCE OF NOTARY HONOR ASSEMBLIES IN THE CRIMINAL JUSTICE PROCESS
}

\author{
Rahmida Erliyani ${ }^{1}$, Achmad Ratomi ${ }^{2}$
}

${ }^{1}$ Fakultas Hukum Universitas Lambung Mangkurat. Jl.Brigjend H.Hasan Basri Banjarmasin 70123 Indonesia Fax: 05114321658 +E-mail : rahmida.erliyani@gmail. com

${ }^{2}$ Fakultas Hukum Universitas Lambung Mangkurat. Jl.Brigjend H.Hasan Basri Banjarmasin 70123 Indonesia Fax:05114321658+E-mail : ratomi79ach@gmail.com

Submitted : 04/03/2018 Reviewed 22/03/2018 Accepted:26/03/2018

\begin{abstract}
The aim of this study is to know and analyze the basic idea of the necessity for the approval of the Notary Honor Assemblies to the Notary examination in the criminal justice process and on the approval of the Notary Honor Assemblies to the Notary examination in the criminal justice process in relation to the principle fast, simple and low cost trial. This research uses doctrinal law research done or aimed at a concept that will be studied which is the concept or principle of fast, simple and low cost trial in relation with the authority of Honorary Notary Assembly to the checking of Notary in criminal justice process. The basic rationale of the existence of this NHA is the effort to enforce the obligation to deny or deny notary rights (the obligation to conceal the contents of the deed). Thus, the NHA's approval as a opening "key" to the obligation of Notaries public when facing the complicated legal process. Legal protection of notary as regulated in Article 66 paragraph (1) law of the Repulic of Indonesia concerning Position of Notary (LPN) is a legal protection to notary public as a public official who is performing its task and obligation in carrying out government authority to keep the state documents in the form of authentic deed. The request for approval from NHA is not only done by the investigator at the stage of investigation, but will also be requested again by the prosecutor for the prosecution and by the judge for the court hearing not in accordance with one of the principles in the criminal justice process that is fast, simple and low cost court principle. For the seizure of the copy of the minuta deed and the summon to the Notaries must first the investigator, the prosecutor and the judge send the application for approval to NHA. It is said not to be in accordance with the simple justice principle because according to Article 66 Law of Position of Notary (LPN), the request for the approval of NHA is done at every stage of criminal justice process.
\end{abstract}

Keywords: Notary Honor Assemblies and criminal justice process. 


\section{INTRODUCTION}

Notary as a public official who runs the profession in providing legal services to the public, need to get protection and guarantee for achieving of legal certainty. Guarantees of protection and assurance for achieving legal certainty on the performance of Notary's tasks have been regulated in Law Number 30 Year 2004 concerning Position of Notary which was then amended by Law Number 2 Year 2014 (hereinafter referred to as LPN).

One of the forms of legal protection provided by Law no. 2 Year 2014 is the formation of the Notary Honor Assemblies who has a task of development to the Notary. This task is a mandate of the Minister of Law and Human Rights which is given to the Notary Honor Assemblies. The provisions on the understanding, tasks and functions of the Notary Honor Assemblies are not regulated in detail in the Notary Law, but such provisions shall be regulated in a Ministerial Regulation as mandated by Article 66A paragraph (3) of the Notary Public Law. As a follow up of the provision of Article 66A Paragraph (3) of the Notary Law, the Minister of Justice and Human Rights issued the Regulation of the Minister of Law and Human Rights (RMLH) No. 7 of 2016 concerning the Notary Honor Assemblies (hereinafter referred to as RMLH No. 7 of 2016) . In 2016, it was stated that "The Notary Honor Assemblies is a body which has the authority to carry out the development for Notary and the obligation to give approval or rejection for the interest of investigation and judicial process, for taking photocopy of Minuta Deed and summoning notary to attend in the checking related to Deed or Notary Protocol which are in the Notary Storage".

Looking at the provisions of the definition of the Honorary Council of Notary above, there are at least 2 main tasks of the Notary Honor Assemblies, which are the development through supervision and assignment of approval in Notary examination by the investigator, public prosecutor and judge. The purpose of this second task according to Article 18 paragraph (2) RMLH no. 7 of 2016 is the Notary Honor Assemblies of Teritory has the function of developement in order to maintain the dignity and honor of Notaries in running his profession; and provide protection to Notary in relation to the obligation of Notary to keep everything on the Deed.

The existence of this Notary Honor Assemblies is like a newborn baby with a different gender. If in Law no. 30 Year 2004 the existence of institution which has function which one of them is giving approval of Notary examination by investigator, prosecutor and judge is Regional Supervisory Council, hence on the change of Law no. 30 of 2004 through Law no. 2 Year 2014, the existence of the institution has changed the gender into the Honorary Council of Notaries. Whereas the authority of the Regional Supervisory Council in the field of approval of the Notaries being checked by the investigator, public prosecutor and judge as regulated in Article 66 paragraph (1) of Law no. 30 of 2004 was deleted by the Constitutional Court through its decision No. 49 / PUU-X / 2012 dated March 23, 2013. In its consideration, the Constitutional Court stated that the phrase "with the article of the Regional Supervisory Council" is contradictory to the Constitution Year 1945 and has no binding legal force. The Constitutional Court stated that the judicial process for taking documents in the notary's depository and summoning notary to attend the checking relating to the documents which it makes does not require the approval of the Regional 
Supervisory Council. The approval procedure is considered to be contrary to the principle of equal protection as guaranteed by the Constitution Year 1945. According to the Court, the Constitution of the different treatment towards notary may be justified as long as the treatment coming under the Notary's Code of Conduct which is the attitude, behavior, and deed of notary dealing with morality. While the notary, as a citizen in the process of law enforcement at all stages, must be treated equally before the law as guaranteed Article 27 paragraph (1) and Article 28D paragraph (3) of the 1945 Constitution. The Constitutional Court considered that the provision requiring RSC approval is contrary to the principle of independence in the judicial process and to the obligation of Notaries as a citizen. In this way, a protracted court process that will result a protracted enforcement of justice can be avoided which can lead to denial of justice itself.

The Constitutional Court's decision in the discussion was ignored by the legislators that in 2014 the legislators of the Law brought back an institution which substantially had the same task and authority which had been declared unconstitutional by the Constitutional Court.

Based on the description above, the author tries to conduct scientific studies on the birth of the authority that has been deleted by the Constitutional Court and relate it to the principle of fast, simple and low cost trial. As for the main issues to be studied are:

1. Why is the approval of the Notary Honor Assemblies (NHA) necessary for to the Notary examination in the criminal justice process?

2. Is the approval of the Notary Honor Assemblies (NHA) for Notary examination in the criminal justice process in accordance with the principle of fast, simple and low cost trial?

\section{METHOD}

The legal research used is normative legal research which is a process to find the rule of law, legal principles and legal doctrines in order to answer the legal issues so as to obtain new argumentation, theory or concept as prescription in solving the problem. ${ }^{1}$

Normative legal research has a tendency in creating an image of law as a prescriptive discipline in which it only sees the law from the viewpoint of its norms, which is certainly prescriptive. Legal science as prescriptive science studies the purpose of law, the values of justice, the validity of the rule of law, legal concepts and legal norms.

This research includes the research on legal principles that is to examine the application of the principle of fast, simple and low cost trial in the process of examining criminal case against Notaries.

In this research there are 2 (two) approach method that has been used, that is statute approach and conceptual approach.

Legal material is the main source for solving legal issues in normative legal research. The Legal material in normative legal research consists of primary legal materials, secondary legal materials and tertiary legal materials.

The technique of collecting legal materials was done by library research it is by tracing the legal materials that have relevance to the subject matter of this study. After all legal materials are collected, the next step is mapping the legal materials in accordance with

1 Peter Mahmud Marzuki. 2005. Penelitian Hukum, Jakarta : Kencana, hlm. 35 
the subject matter. Computerization is done to facilitate the mapping process by putting the legal materials into file/folder in accordance with the items of discussion.

The way of processing legal substances is done inductively by drawing conclusions from a concrete problem which is specific to general abtsract problems. Furthermore, the existing legal materials are analyzed descriptively beginning with grouping the same legal material according to the sub aspect and then doing the interpretation to give meaning to each sub aspect and its relation to each other. After that an analysis is done to the whole aspects to understand the meaning of the relation of one aspect among the others and the whole aspects of the subject of research problems are done inductively so as to give a full picture of the results. ${ }^{2}$

\section{ANALYSIS AND DISCUSSION}

The Requirements Of The Approval Of Notary Honor Assemblies For Notary Examination In The Criminal Justice Process

One of the obligations of notaries in carrying out their position is to make deed in the form of minuta deed (which is the original deed of notary), and keep it as part of notary protocol. Notary protocol is a collection of documents which are state archives that should be kept and maintained by Notaries. The obligation to maintain the confidentiality of the contents of the Deed, Grosse Deeds, copiy of Deed, or Deed Citations made by and in the supervision of Notaries has been described in several articles in the LPN, such as:

1. Article 4 paragraph (2) : the oath as referred to in paragraph (1) shall read as

2 Bahder JohanNasution. 2008. Metode Penelitian Ilmu Hukum. Bandung: CV Mandar Maju, hlm. 166 follows "that $i$ will keep secreet the content of the deed ans statement obtained in the performance of my office".

2. Article 16 paragraf (1) letter $\mathrm{f}$ : In carrying out his post, Notary shall : keep everithing on the deed he made and all information obtained in order to manufacture in accordance with the deed of oath / pledge of office, unless the statue otherwise provide.

3. Article 54 : Notaries can only give, show, or notify the contents of the Deed, Grosse Deed, copy of Deed or Deed Citation, the person concerned directly on the deed, heirs, or person who are entitled, unless otherwise provide by legislation.

Acording to that provision, Notaries due to their position shall be given to have a right of refusal or a Verschonings recht, as well as a obligation of refusal (Verschonings) which is the right to be exempted to give information related with the deed he made and the obligation to refuse to give any information. It is also stipulated in Article 1909 Paragraph (3) of the Civil Code which says "all individuals competent to be a witnesses are required to submit their testimonies in court. The following individuals may be excused from testifying: anyone who due to their status, position or function, is pledged to secrecy, but only to the extent of the information entrusted to them in connection with their above-mentioned status position or function."

In the scope of criminal law, there is also a provision on that matter in Article 322 of The Criminal Law which states, "Any person who will deliberate intent reveals that he by reason of either his present or earlier office or profession is obliged to keep secret shall be punished with maximum imprisonment of nine months or maximum fiine of Rp.9.000,00." 
Therefore, notaries must keep the content of the deed, and the information obtained in the notarial deed, unless ordered by law that notaries are not required to keep everything on the deed and provide necessary information related to the deed. The regulation on the obligation to keep the secrecy in relation to the criminal justice process has been regulated in Article 170 of the Criminal Procedure Law which says:

(1) Those who because of their occupation, dignity or office are obliged to mantain confidentially, may asked to be excused from the obligation to testify as witnesses, specially concerning matters entrusted to them.

(2) The judge shall determine the validity or invalidity of any and all reasons for such requests.

Considering the position of Notaries is a position based on trust, the trust between Notaries and a party who uses their services, so the Notaries required to keep the content on the deed and the information obtained in the notarial deed, unless ordered by law that the Notaries not required to keep everything on the deed and to give the information relating to the deed.

One of the exceptions of concealing the contents of the deed is that notaries may display the deed contents and provide a copy of the deed to law enforcement for criminal proceedings. This is as regulated in Article 66 paragraph (1) of LPN which says: "For the purposes of judicial preceedings, ivestigators, prosecutors, or judges with the approval of the competent Notary honor assemblies: take a photocopy of Minuta Deed or in storage Notary Botary Protocol; and Notary summoned to be present in the examination to the Deed or protocols that are in storage Notary".
The Politic of Law ${ }^{3}$ of the provisions of Article 66 Paragraph (1) LPN can be seen from several reasons both proposed by the House of Representatives and the President in the LPN review (pengujian) which took place in 2012 and in 2014 and it can be summarized as follows:

The making of LPN is not detaining the process of investigation, it can be seen from the redaction construction of sentence in Article 66 paragraph (1) which says "

1. The making of LPN is not detaining the process of investigation, it can be seen from the redaction construction of sentence in Article 66 paragraph (1) which says "For the purposes of judicial preceedings, ivestigators, prosecutors, or judges with the approval of the competent Notary honor assemblies: take a photocopy of Minuta Deed or in storage Notary Botary Protocol; and Notary summoned to be present in the examination to the Deed or protocols that are in storage Notary";

The editorial construction of this chapter opens a wide opportunity for investigators to obtain evidence to clarify the investigation process and it is appropriate that RSC provide the necessary evidences

3 Menurut Mahfud MD "Politik Hukum" adalah legal policy atau garis (kebijakan) resmi tentang hukum yang akan diberlakukan baik dengan pembuatan hukum baru maupun dengan penggantian hukum lama, dalam rangka mencapai tujuan negara. Dengan demikian politik hukum merupakan pilihan tentang hukum-hukum yang akan diberlakukan sekaligus pilihan tentang hukumhukum yang akan divabut atau tidak diberlakukan yang kesemuanya dimaksudkan untuk mencapai tujuan negara seperti yang tercantum di dalam Pembukaan UUD 1945. Lihat Moh. Mahfud MD. 2014. Politik Hukum di Indonesia, Jakarta: PT. Rajagrafindo Persada, hlm.1. 
for the purpose of investigation. a unique case then appears where the RSC does not give permission was another matter which could not be the reason to blame the redaction of the regulation in Article 66 of Notary Law which is contradictory to the Constitution of the Republic of Indonesia Year 1945.

2. If the MKN does not give approval to the Investigator to take photocopies of minuta deeds and or letters which are attached to Minuta Deeds or notary protocol in the storage Notary, then the Police as the investigator and it is appropiate that the law enforcers propose other efforts to obtain the tools of evidence, for example by filing an application to the District Court to provide an appointment to take the copy of Minuta Deed attached to the Minuta deed or notary protocol for the sake of progress of the investigation process. Thus, this is not a normative issue but an enrichment of ways that can be taken by law enforcers in collecting evidence.

3. The legislation ratio is as an effort to enforce the obligation of refusal or notary right of refusal (the obligation to conceal the contents of the deed). Therefore, NHA's approval as a opening "key" to the obligation of refusal when facing the complicated legal process (initial investigation, investigation, prosecution, and court proceedings). The final result of the examination is the approval or Refusal of the request of the investigator, the public prosecutor, and the judge concerning the contents of the deed, photocopy of minuta, or other letter. The complexity of duties and obligations, as well as guarantees of the use of the Notary right of refusal in performing their tasks requires standard of protection by forming NHA as a form of protection for Notary. Therefore, Article 66 Paragraph (1) of LPN is to provide protection and equality before the law to the notary in giving statements in the legal process.

The existence of MKN with all its authority is to guarante the implementation of legal protection for the Notaries, but on the other hand it has violated one of the characteristics of the state law, the fundamental law priciple, namely as equality before the law. Satjipto Raharjo summoned this legal principle as the "heart" of the rule of law, because: ${ }^{4}$

1. Law principles are the most widely foundation for the birth of a rule of law, it means that the rules of law can ultimately be restored to the law principles.

2. The Law principle is worth mentioning as the reason for the birth of the rule of law, or is the legis ratio from the rule of law.

This law principle will not run out its strenght by giving birth of a rule of law, but it still deliver the next rules.

One of the law principles in the criminal procedure law as mentioned in The criminal Code (KUHP), in the General Provisions point 3 letter a is equality before the law. The principle states that everyone should be treated equally before the law, no favoritism or partiality, all should receive equal treatment and rights. with this principle, the criminal justice system always prioritizes the equality so that anyone and any conditions of any legal subject that wants service in the solving of legal mattes should be regarded and treated equally, and should avoid discrimination by

4 Ramelan. 2006. Hukum Acara Pidana (Teori dan Implementasinya). Jakarta: Sumber Ilmu Jaya, hlm. 2 . 
not prioritizing or putting the rich first and ignoring or abandoning the less or the poor.

Equality Before The Law Priciple constitutionally stipulated in Article 27 paragraph 1 of the 1945 Constitution of 1945 which says "All citizens have equal status before and in government and shall abide by the law and the government without any exception." This provision is also stipulated in Article 28D paragraph (1) of the Constitution 1945 says, "every person shall have the rights of recognition, guarantees, protection and certainty before a just law, and of equal treatment before the law". This provision can be regarded as one of the manifestations of non-discrimination guarantee as regulated in Article 28I paragraph (2) of the Constitution of the Republic of Indonesia 1945: "Every person shall have the right to be free from discriminative treatment based upon any grounds whatsoever and shall have the right to protection from such discriminative treatment"

Relating to the existence of Article 66 Paragraph (1) in The Law of Position of Notaries (LPN), the judicial process by the investigator, prosecutor, or judge to retrieve the documents in the notary's depository and summon the notary to attend the examination relating to the documents he made can only be done with NHA approval, It is one of the regulation which should not contain any different treatment which is against the principle of equal protection as guaranteed by Article 27 paragraph (1) and Article 28D paragraph (3) of the Republic of Indonesia Constitution 1945 (UUD 1945), summoned the equality before the law and government principle. The different treatment can be justified as long as the treatment is related to the action within the scope of the code of ethics related to the attitude, behavior, and the act of notaries in per- forming tasks related to morality. The different treatment towards the position of notaries regulated and given protection in the Code of Ethics of Notaries, whereas the notaries as citizens in the process of law enforcement at all stages must be treated equally before the law as intended and guaranteed by Article 27 paragraph (1) and Article 28D paragraph 3) of the Republic of Indonesia Constitution 1945. Therefore, the requirement of NHA approval contradicts the principle of independence in the judicial process and the obligation of notaries as citizens who have equal position before the law. In this way, there will not be a protracted judicial process that will result a protracted the enforcement of justice which will lead to the denial of justice itself at the end.

The Approval Of Notary Honor Assemblies To The Examination Of Notaris In The Criminal Justice Process In Relation With Quick, Simple And Low Cost Trial Principle

The existence of NHA in performing its tasks as described above, not only violating the principle of equality before the law but also violating judicial independence, it will also complicate and elongate the process of inspection in criminal law enforcement. The request for approval from the NHA is not only carried out by the investigator at the investigation stage, but will also be requested by the prosecutor for the prosecution and by the judge in the course of the court hearing. As well as the position of the Notary in the judicial process, whether only the Notary as a witness or suspect, or including as an expert. Although the author considers that the Notary is only a witness or suspect based on the reasons for the interest of the inspection of 
Notary only relates to the request for a copy of the deed and other documents related to the Minuta Deed. It is impossible that Notary as an expert will be questioned related to the contents of the deeds he made. However, because Article 66 LPN and RMLH no. 7 Year 2016 do not explain explicitly about the position of Notary in the criminal justice process, there will be multiple interpretations which will ultimately be regarded that the notary as an expert must also go through the approval of NHA.

According to the Government as its statement in the Decision of the Constitutional Court. 72 / PUU-XII / 2014, it is said that when Law no. 30 of 2004 is compared with the Law no. 2 Year 2014, there is a provision stating the existence of time limitation as regulated in Article 66 paragraph (3) and paragraph (4), it is 30 (thirty) working days since the application by NHA has been received, then NHA must have given its answer. If it exceeds the time limit NHA does not provide an answer, then the request is deemed approved. The addition of Paragraphs 2 and 3 of Article 66 in the LPN according to the Author only regulates the procedural provisions in publishing the approval letter, not to state the essence of giving back the authority as possessed by the Regional Supervisory Council contained in Law no. 30 in 2004.

The existence of Article 66 of the LPN can be considered to be inconsistent with one of the principles in the criminal justice process, called the quick, simple and low cost trial. In Article 2 paragraph (4) of Law Number 48 Year 2009 concerning Judicial Powers states that "Adjudication must be carried out quickly, simply, and at low cost" Furthermore Article 4 paragraph (2) of Law no. 48 Year 2009 also requires the existence of this prin- ciple, it says "Pengadilan membantu pencari keadilan dan berusaha mengatasi segala hambatan dan rintangan untuk dapat tercapainya peradilan yang sederhana, cepat, dan biaya ringan". Penjelasan Pasal 2 ayat (4) tersebut menyatakan bahwa yang dimaksud dengan "sederhana" adalah pemeriksaan dan penyelesaian perkara dilakukan dengan cara efesien dan efektif. "Courts help justice seekers and try to overcome all detentions and obstacles and in order to achieve a simple, quick, and low cost trial". Elucidation of Article 2 paragraph (4) states that what is meant by "simple" is examination and settlement of the case done in efficient and effective way.

The meaning of the word "light cost" is the cost of the cases that can be paid by the community. However, the simple, quick, and low trial principle in the examination and the settlement of cases in court does not put aside precision and accuracy in seeking truth and justice.

The Criminal Procedure Law as one of the legal basis used by law enforcer in the process of investigation, prosecution and court, also includes simple, quick and low cost trial principle. This provision is contained in the General Provisions point 3 letter e which says "Adjudication, which must be carried out quickly, simply, and at low cost in a free, honest and impartial manner, must be realized consistently at levels of justice". Furthermore, it can also be seen in Article 56 paragraph (1) of Law of Criminal Procedure which says "In the event a suspect or an accused is suspected of or accused of having committed an offense which is liable to a death penalty or imprisonment of fifteen years or more or for those who are destitute who are liable to imprisonment of five years or moe who do not have their own legal counsel, the official concerned 
at all stages of examination in the criminal justice process shall be obligated to asssign legal counsel for them." The explanation of the article states that realizing the principle of justice shall be executed in a simple, fast and low cost and also with consideration that those who are sentenced to less than five years shall not be subject to detention except for the offenses referred in Article 21 paragraph (4) letter b, therefore for those sentenced to five years in prison or more, but less than fifteen years, the appointment of his or her legal counsel shall be adjusted to the progress and circumstances of the availability of legal counsel in that place.

The provision of Article $66 \mathrm{LPN}$ is deemed not to adhere quick justice principles because in order to seizure the copy of minuta deed and summon the Notary the investigator, prosecutor and judge must first send the application letter of approval to NHA. The requirement of such approval and the time limit stated in Article 66 paragraph (3) and (4) LPN will affect the period of detention if the Notary is a suspect/ defendant.

It is said that it is not in accordance with the simple justice principle in Article 66 LPN, the request for NHA approval is done at every stage of the judicial process, which is conducted by the investigator, at the prosecution stage conducted by the public prosecutor and by the judge at the judicial examination stage. It is better that the approval agreement is carried out only by the investigator and then the public prosecutor and judge are no longer required. The approval file of the NHA is sufficient to be the basis of the prosecutor at the time of delegating his case to the court and the basis for the judge to examine the case in court. If there is a provision states that taking a copy of minuta deeds can only be done through foreclosure action is only the authority of the investigator. According to Article 1 Sub-Article 16 of the Criminal Procedure Code, Foreclosure is a series of investigative actions to take over and or to retain under the control of immovable or immovable, tangible or intangible objects for the purpose of proof in investigation, prosecution and trial. Furthermore, Article 38 Paragraph (1) of the Criminal Procedure Code states "Confiscation can only be carried out by the investigator with the permission of the local district court chief'. The official authorized to foreclose is only an investigator. Whereas the prosecutor and the judge are not authorized to foreclose. If the prosecution still requires foreclosure, the prosecutor orders the investigator to prosecute. If in the court hearing the judge considers that foreclosure is necessary, the judge may order the prosecutor to investigate the foreclosure.Therefore, whether the public prosecutor and the judge still have to make a letter of application for NHA approval if it wants to take (by foreclosure) a copy of the minuta deed.

This lack of simplicity can also be seen from the provisions of Article 27 paragraph (2) RMLH. 7 of 2016 stating that "the Regional Notary Public Notary may accompany the Notary in the process of investigation in the presence of the investigator. The question is whether this authority applied only to Notary as a suspect or also as a witness and an expert? The Criminal Procedure Code only gives the right to the suspect to obtain legal assistance in the form of assistance at the time of investigation by the investigator. It as regulated in Article 54 of the Criminal Procedure Code which says "For the purpose of defense, the suspect or defendant is entitled to legal assistance from one or more legal coun- 
sels during and at each level of investigation, according to the procedure prescribed in this law". As for witnesses and experts the Criminal Procedure Code does not provide the right for assistance

The principle of low cost trial will also be ruled out by the existence of Article 66 of the LPN, which will require additional funds at the time of submitting the application for approval of NHA. Isn't the NHA that will give the approval is the NHA which is located in the capital of the province? Besides the judicial process involving Notaries can not only occure in the Capital of province, but also in other regencies/cities that relatively have close distance. especially if the Notary who is asked for a copy of the minuta deed or Notarial deeds is in different territory (province) from the province (province) of investigators, prosecutors and judges.

\section{CONCLUSION}

The basic rationale of the NHA existence is the effort to enforce the obligation of refusal or notary right of refusal (the obligation to conceal the contents of the deed). Thus, NHA's approval is as a opening "key" to the obligation of refusal when facing the complicated legal process (initial investigation, investigation, prosecution, and court proceedings). Legal protection for notaries regulated in Article 66 paragraph (1) LPN is legal protection for notary public as a public officials performing its task and obligation in carrying out government authority to keep the state documents in the form of authentic deed. The protection of the law is not granted to a notary as a person but rather emphasized to the Notary as a public officials.

The existence of NHA in carrying out its tasks will also complicate and prolong the investigation process in criminal law enforcement. The request for approval from the NHA is not only carried out by the investigator at the investigation stage, but will also be requested by the prosecutor for the prosecution and by the judge for the court hearing not in accordance with one of the principles in the criminal justice process, summoned the quick, and low cost trial. For the foreclosure of the copy of the minuta deed the summon for the Notary, the investigator, the prosecutor and the judge must first send the application for approval to NHA. It is considered not in accordance with the simple justice principle because in Article $66 \mathrm{LPN}$, the request for NHA approval is done at every stage of judicial process, that the investigation stage of the petition conducted by the investigator, at the prosecution stage conducted by the public prosecutor and at examination stage in court conducted by the judge.

\section{BIBLIOGRAPHY}

Marzuki, Peter Mahmud. 2005. Penelitian Hukum. Jakarta : Kencana. Ramelan, 2006. Hukum Acara Pidana (Teori dan Implementasinya). Jakarta: Sumber Ilmu Jaya. Nasution, Bahder Johan. 2008. Metode Penelitian Ilmu Hukum. Bandung: CV Mandar Maju.

\section{Peraturan Perundang-Undangan}

Undang-Undang Republik Indonesia Nomor 8 tahun 1981 tentang Hukum Acara Pidana

Undang-Undang Republik Indoensia Nomor 30 Tahun 2004 tentang Jabatan Notaris Undang-Undang Republik Indoensia Nomor 2 Tahun 2014 tentang Perubahan Atas Undang-Undang Nomor 30 Tahun 2004 tentang Jabatan Notaris Putusan Mahkamah Konstitusi repub- 
Lambung Mangkurat Law Journal $\square$ Vol 3 Issue 1, March (2018)

lik Indonesia Nomor 49/PUU-X/2012

Putusan Mahkamah Konstitusi republik Indonesia Nomor 72/PUU-XII/2014

Peraturan Menteri Hukum dan Hak Asasi Manusia Republik Indonesia Nomor 7 Tahun

2016 tentang Majelis Kehormatan Notaris 